\title{
EFFECTS OF HYDROGEN PEROXIDE WITH CASSAVA EXTRACT ADDITION AS BLEACHING MATERIAL ON HUMAN ENAMEL- AN IN VITRO STUDY
}

\author{
Kavita1 , Trimurni Abidin², Saharman Gea ${ }^{3}$
}

1 Faculty of Dentistry, Master of Dental Sciences, Universitas Sumatera Utara, Medan, Indonesia.

${ }^{2}$ Faculty of Dentistry, Department of Conservative Dentistry, Universitas Sumatera Utara, Medan, Indonesia.

${ }^{3}$ Faculty of Mathematics and Sciences, Department of Chemistry, Universitas Sumatera Utara, Medan, Indonesia.

\section{ABSTRACT}

\section{BACKGROUND}

Bleaching procedures can lead to loss of minerals and morphological changes of the enamel. In order to minimize the damage on enamel, there is a need to develop natural ingredients from cassava tubers as additives for bleaching material because it contains calcium, phosphate and enzymes.

The aim of this study is to evaluate the difference of morphology and elements of the enamel after bleaching with different concentrations of hydrogen peroxide and hydrogen peroxide with cassava extract as additive material.

\section{MATERIALS AND METHODS}

Six third molars were used in this study by first causing teeth discolouration. And then, the teeth were cut in the mesio-distal direction and buccal surface was divided into 4 Groups, Group I was bleached with hydrogen peroxide 10\%, Group II was bleached with a mixture of hydrogen peroxide and $10 \%$ cassava extract, Group III was bleached with hydrogen peroxide 35\% and Group IV was bleached with a mixture of hydrogen peroxide 35\% and cassava extract. Changes in enamel morphology were observed by a Scanning Electron Microscope (SEM) and Atomic Force Microscope (AFM), whereas elements of enamel were analysed with Energy Dispersive X - Ray (EDX). Statistical analysis was performed by ANOVA Test.

\section{RESULTS}

The results showed that in all Groups, there were significant differences in the Ca and P elements, while the chemical elements C and $\mathrm{O}$ had no significant differences. In Group II and Group IV there was reduction of damage to the enamel, and morphology as seen through the SEM and AFM as compared to Groups I and III.

\section{CONCLUSION}

Adding cassava extract as additive material to bleaching material can increase the mineral on enamel and decrease the effects on enamel morphology.

\section{KEY WORDS}

Cassava, Chemical Element, Hydrogen Peroxide, Morphology, Enamel

HOW TO CITE THIS ARTICLE: Kavita, Abidin T, Gea S. Effects of hydrogen peroxide with cassava extract addition as bleaching material on human enamel- an in vitro study. J. Evolution Med. Dent. Sci. 2019;8(10): 689-695, DOI: 10.14260/jemds/2019/153

\section{BACKGROUND}

Teeth discoloration can cause aesthetic problems on teeth, which could create psychological effects such as lower levels of self-confidence. ${ }^{1}$ This happens because enamel is permeable, hence colours from food and drinks tend to fill the porous structure of enamel and bind with enamel organic matrix. ${ }^{2}$ Bleaching is one of the aesthetic treatments that could whiten teeth through chemical reactions with bleaching materials such as hydrogen peroxide.3, 4, 5 The concentration of hydrogen peroxide that can be used for teeth bleaching ranges from $5 \%$ to $35 \%{ }^{4}$ During the process of bleaching, peroxide materials will produce free radicals and interact with teeth to make teeth whiter. ${ }^{5}$

'Financial or Other Competing Interest': None.

Submission 17-01-2019, Peer Review 22-02-2019,

Acceptance 28-02-2019, Published 11-03-2019.

Corresponding Author:

Trimurni Abidin,

Jl. Alumni No. 2

Padang Bulan, Kampus USU,

Medan Baru, Medan City,

North Sumatera-20155, Indonesia.

E-mail: triabidin@yahoo.com

DOI: $10.14260 /$ jemds $/ 2019 / 153$

\section{(c) (i) $(9)$}

Previous studies have reported the effects of enamel damage from various points of view due to exposure to bleaching materials, including morphological changes, increased roughness, decreased enamel hardness, loss of mineral composition, increased enamel permeability and increased risk of enamel caries. ${ }^{6-9}$

Morphological changes can be found on enamel surfaces using Scanning Electron Microscope such as enamel surface irregularities, loss of aprismatic enamel layer, depression, porosity, crater, erosion, and groove on enamel due to bleaching material.10-13 Saleem (2015) in his research found enamel surfaces look rough after the application 36\% hydrogen peroxide bleaching material with AFM. Microporosity and enamel roughness can also increase when using higher concentration of peroxide, this has been proven by Berger's research with using $\mathrm{H}_{2} \mathrm{O}_{2} 35 \%$ bleaching material and can cause the mineral content of $\mathrm{Ca}$ and $\mathrm{P}$ to reduce greater as when compared to using $\mathrm{H}_{2} \mathrm{O}_{2} \quad 10 \%$ bleaching material.14 Decrease of $\mathrm{Ca}$ and $\mathrm{P}$ elements was also found in the results of the study by Syafriadi and Noh (2014), which showed calcium solubility as many as $1.016 \mathrm{ppm}$ was found in the control Group and as many as 2, 607 ppm was found in the $10 \%$ hydrogen peroxide Group by using atomic absorption spectrophotometry. ${ }^{8}$ Venkatesan et al. (2012) also found Raman spectroscopy in their study that phosphate 
elements before bleaching showed mean and standard deviation value as $975.69 \pm 4.52$ and after bleaching with $\mathrm{H}_{2} \mathrm{O}_{2} 38 \%$ showed mean and standard deviation value as $817.43 \pm 12.96 .{ }^{14}$ Gopinath et al. (2013) in his study found a decreased effect on enamel morphology by adding sweet potato extract into bleaching material namely $\mathrm{H}_{2} \mathrm{O}_{2}$ of $10 \%$ and $35 \%$ concentration, as compared to bleaching materials without sweet potato extract.(15)

Indonesia is a country which rich in cassava plants and is the fourth largest cassava producer in the world as reported by FAO (Food and Agriculture Organization of the United Nations). According to FAO data in 2017, the top of five cassava producing countries are Nigeria (59 million tons), Republic of the Congo (31 million tons), Thailand (30 million), Indonesia (19 million tons), and Brazil (18 million tons). ${ }^{16,17}$ Cassava plants are tuber plants which containing calcium, phosphate, and enzymes such as catalase, anthocyanins (flavonoids), polyphenols, phytic acid and oxalate acid. ${ }^{18}$ There is currently no research that discusses that cassava plants can used to reducing the effects of mineral composition and morphology damage on enamel surfaces post whitening of teeth. The purpose of this study is to evaluate the morphology and elements of enamel minerals if cassava extract is added to $10 \%$ and $35 \% \mathrm{H}_{2} \mathrm{O}_{2}$ bleaching material.

\section{MATERIALS AND METHODS}

\section{Preparation of Cassava Extract}

About 400 grams of raw cassava were washed with water, the outer skin was peeled and then cut into cubes. The square piece of tuber was smashed with $50 \mathrm{ml}$ of deionized water in a blender until homogeneous and then filtered. The resulting cassava liquid was cooled in a ice bath at $4{ }^{\circ} \mathrm{C}$ first, and then centrifuged (VS-6000Cfi, Korea) with $2000 \mathrm{rpm}$ speed for two minutes. The liquid of cassava extract was kept in plastic bottle and stored at refrigerator with $4^{\circ} \mathrm{C}$ temperature until it is used. ${ }^{11}$

\section{Preparation of Mixture Cassava Extract with Bleaching Material}

Bleaching material $\mathrm{H}_{2} \mathrm{O}_{2} 10 \%$ with cassava extract was mixed by using $9 \mathrm{ml}$ cassava extract, $84 \mathrm{ml}$ phosphate buffered saline (PBS), and $3 \mathrm{ml}$ of $10 \% \mathrm{H}_{2} \mathrm{O}_{2}$ solution into a glass beaker and then stirred with stirring glass rod and vortex (Ika Vortex 3 Shaker, England) until homogeneous to produce $96 \mathrm{ml}$ of treatment material in Group II. The mixture of $\mathrm{H}_{2} \mathrm{O}_{2}$ $35 \%$ bleaching with cassava extract followed a similar preparation method of mixture cassava extract with $10 \%$ $\mathrm{H}_{2} \mathrm{O}_{2}$ bleaching material above, but instead utilised $9 \mathrm{ml}$ cassava extract, $84 \mathrm{ml}$ phosphate buffered alkaline (PBS), and $3 \mathrm{ml} \mathrm{H} \mathrm{O}_{2} 35 \%$ solution to produce $96 \mathrm{ml}$ of the treatment material that will be used in Group IV in this study (Modified Gopinath). ${ }^{15}$

\section{Preparation of Sample}

Six human third molars were taken as samples. The extracted third molars teeth were obtained from RSGM USU with the criteria of age 18-35 years, crowns and roots were completely formed, no caries, and no discoloration of teeth. The collected teeth were soaked with saline solution for 1 week. All tooth roots were cut at the cement-enamel junction (CEJ) with a disc bur and water spray like in Figure 1A. Each crown is cut

into two parts in the mesiodistal direction (Figure 1B), and then the buccal part of the dental crown which is part of the treatment will be divided again into 4 pieces in the horizontal and vertical direction (Figure 1C) to obtain 24 pieces of buccal surface samples. A total of 24 sample pieces were taken randomly and divided into 4 Groups, namely as follows-

1. Group I: Bleaching with $\mathrm{H}_{2} \mathrm{O}_{2} 10 \%$ solution.

2. Group II: Bleaching with a mixture of $\mathrm{H}_{2} \mathrm{O}_{2} 10 \%$ solution and cassava extract.

3. Group III: Bleaching with $\mathrm{H}_{2} \mathrm{O}_{2} 35 \%$ solution.

4. Group IV: Bleaching with a mixture of $\mathrm{H}_{2} \mathrm{O}_{2} \quad 35 \%$ solution and cassava extract.

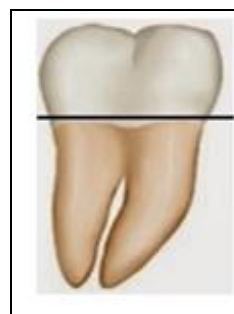

A
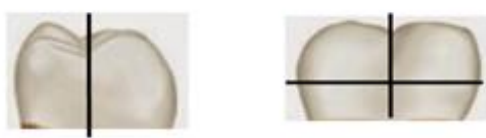

B

\section{C}

\section{Figure 1. Tooth Cutting Procedure to Obtain Samples A. Cutting of Tooth Roots Near CEJ \\ B. The Crown is Divided in a Horizontal Direction (Mesial-Distal) \\ C. The Buccal Crown is Divided in Horizontal and Vertical Directions}

\section{Preparation and Soaking Samples for Tooth Discoloration}

All samples in the study were immersed in coffee liquid to create tooth discoloration. As much as 2 grams of coffee powder (Nescafe classic) were mixed with $100 \mathrm{ml}$ of deionized water and heated with using a lamp spirit until boiling while stirring with a stirring rod until the coffee solution is evenly distributed and then the coffee solution was cooled. All samples from Groups I, II, III and IV were soaked with $3 \mathrm{ml}$ of cold coffee solution each for 5 days in a closed plastic container, and then samples rinsed with water, dried with tissue and then prepared for the bleaching procedure.

\section{Bleaching Procedure}

Each sample in Group I was immersed with $3 \mathrm{ml}$ of $10 \% \mathrm{H}_{2} \mathrm{O}_{2}$ solution for 10 minutes, where the bleaching material was replaced every 10 minutes with 3 times by removing the old solution and replacing with $3 \mathrm{ml}$ of a new solution so that the material used within 30 minutes is $9 \mathrm{ml}$, and then the sample is rinsed with distilled water and dried with tissue first. After the bleaching procedure was completed for 30 minutes, each sample was immersed in artificial saliva (pH 6.8) for 1 week. And then carried out again the bleaching procedure in the same way as above, the sample is soaked for 30 minutes by replacing material 3 times every 10 minutes. After the bleaching procedure is completed, the sample is soaked with artificial saliva ( $\mathrm{pH}$ 6.8) for 24 hours, and then rinsed with distilled water and dried with tissue. All samples in Group III went through a bleaching procedure in the same way as in Group I, but was carried out with $\mathrm{H}_{2} \mathrm{O}_{2} 35 \%$ bleaching material. 
Each sample in Group II was bleached with a mixture of $\mathrm{H}_{2} \mathrm{O}_{2} 10 \%$ and cassava extract, which treatment then for all samples in Group II is similar in Groups I and III. Samples in Group IV were also soaked with the bleaching procedure in the same way as in Group II with a mixture of $\mathrm{H}_{2} \mathrm{O}_{2} 35 \%$ with cassava extract. All methods of treatment with bleaching materials in each Group can be seen in Figure 2 (Modified Gopinath). ${ }^{15}$

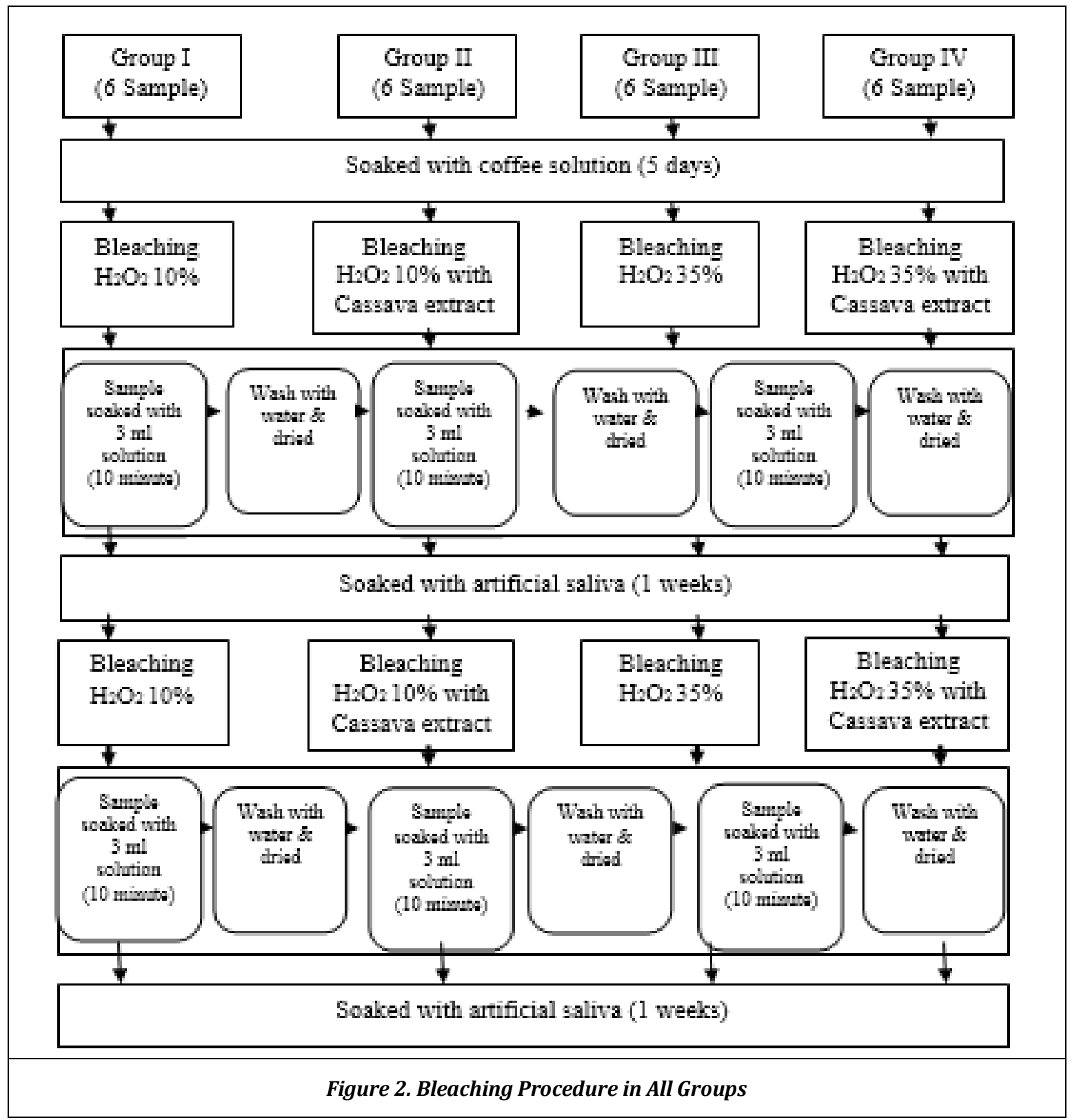

\section{Examination and Analysis of Samples}

After completing the bleaching procedure for all Groups, only one sample from each Group was taken and analysed enamel morphology by using a scanning electron microscope (EVO/MA10 ZEISS, Germany) with 2000 magnification and using an atomic force microscope (Dimension Edge Bruker, USA) with an area of $70 \times 70 \mu \mathrm{m} 2$, where the tip of the silicon probe (Tap300-G, sensor budget, Bulgaria) contacts the surface of the sample with tapping mode (Intermittent contact). All samples from all Groups were analysed using energy dispersive x-ray (EVO/MA10 ZEISS, Germany) to determine the number of elements $\mathrm{Ca}, \mathrm{P}, \mathrm{C}$ and $\mathrm{O}$ (\% weight) on the enamel surface. ${ }^{13}$ Quantitative data obtained from EDX analysis will be tested with one-way variance analysis (ANOVA) with a significant level $(\alpha=0.05)$ to determine differences in chemical elements (Ca, P, C and O) in Groups I, II, III and IV.

\section{RESULTS}

The results of the examination showed elements (Ca), phosphate $(\mathrm{P})$, carbon $(\mathrm{C})$, and oxygen $(0)$ from energy dispersive $\mathrm{x}$-ray is shown in Table 1 Significant differences in the chemical elements Ca and $P(p<0,05)$ and no differences in elements $C$ and $0(p>$ 0.05 ) were found in all Groups. 


\begin{tabular}{|c|c|c|c|c|c|c|c|c|}
\hline \multirow[t]{2}{*}{ Group } & \multicolumn{2}{|c|}{$\begin{array}{c}\text { Ca } \\
\text { (\% Weight) }\end{array}$} & \multicolumn{2}{|c|}{$\begin{array}{c}\mathrm{P} \\
\text { (\% Weight) }\end{array}$} & \multicolumn{2}{|c|}{$\begin{array}{c}\text { C } \\
\text { (\% Weight) }\end{array}$} & \multicolumn{2}{|c|}{$\begin{array}{c}0 \\
\text { (\% Weight) }\end{array}$} \\
\hline & Mean \pm SD & $\mathbf{p}$ & Mean \pm SD & p & Mean $\pm S D$ & $\mathbf{p}$ & Mean \pm SD & $\mathbf{p}$ \\
\hline I & $23,00 \pm 6,92$ & \multirow{4}{*}{$0,017^{*}$} & $8,93 \pm 2,49$ & \multirow{4}{*}{$0,019^{*}$} & $6,04 \pm 2,19$ & \multirow{4}{*}{0,351} & $18,73 \pm 9,61$ & \multirow{4}{*}{0,992} \\
\hline II & $28,61 \pm 7,29$ & & $12,5 \pm 3,99$ & & $8,62 \pm 6,24$ & & $19,21 \pm 16,52$ & \\
\hline III & $14,30 \pm 2,85$ & & $7,42 \pm 1,46$ & & $4,83 \pm 2,60$ & & $17,00 \pm 3,98$ & \\
\hline IV & $19,83 \pm 4,30$ & & $9,26 \pm 1,95$ & & $6,37 \pm 2,27$ & & $18,58 \pm 5,19$ & \\
\hline
\end{tabular}

\section{Information}

1. Group I: Bleaching with $\mathrm{H}_{2} \mathrm{O}_{2} 10 \%$ solution.

2. Group II: Bleaching with a mixture of $\mathrm{H}_{2} \mathrm{O}_{2} 10 \%$ and cassava extract.

3. Group III: Bleaching with $\mathrm{H}_{2} \mathrm{O}_{2} 35 \%$ solution.

4. Group IV: Bleaching with a mixture of $\mathrm{H}_{2} \mathrm{O}_{2} 35 \%$ and cassava extract.

The highest average elements of Ca, P, C and $\mathrm{O}$ were found in Group II which was treated with $\mathrm{H}_{2} \mathrm{O}_{2} 10 \%$ bleaching material with cassava extract. Meanwhile, the lowest was in Group III which was treated with $\mathrm{H}_{2} \mathrm{O}_{2} 35 \%$ bleaching material as shown in Figure 3. The average elements of $\mathrm{Ca}, \mathrm{P}, \mathrm{C}$, and $\mathrm{O}$ in Group II which was treated with $\mathrm{H}_{2} \mathrm{O}_{2} 10 \%$ bleaching material with cassava extract was found higher than Group I which was only treated with $\mathrm{H}_{2} \mathrm{O}_{2} 10 \%$ bleaching material. Additionally, elements in Group III which was exposed with a mixture $\mathrm{H}_{2} \mathrm{O}_{2} 35 \%$ bleaching material and cassava extract was higher than Group IV which was only exposed with $\mathrm{H}_{2} \mathrm{O}_{2} 35 \%$ bleaching material.

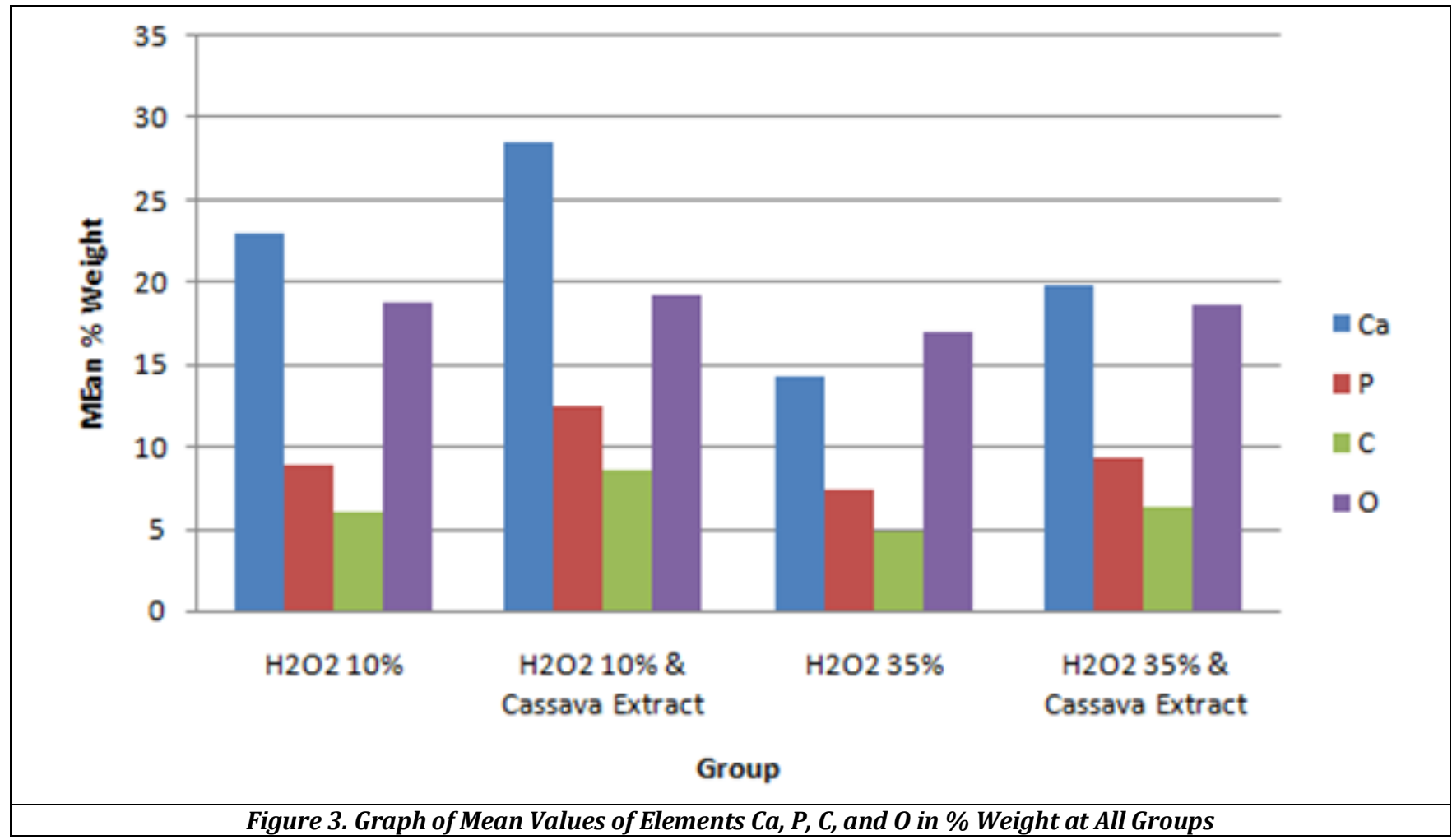

The results of SEM examinations on enamel surfaces with a magnification of 2000 times showed that Group I after exposure $10 \% \mathrm{H}_{2} \mathrm{O}_{2}$ bleaching material shows surface irregularities with many depression and erosion (Figure 4A); and also showed a rough surface with many sharp and thin peaks on AFM examination (Figure 4B). However, surface irregularities look reduced with less depression and erosion in SEM, and also the surface looks smoother in AFM after exposure mixture of $\mathrm{H}_{2} \mathrm{O}_{2} 10 \%$ bleaching material with addition of cassava extract in Group II (Figures 5A and 5B).

Large and wide of crater formation, extensive erosion, and large and deep depression were found in SEM, and the surface looks more severely damaged with sharp and wide peaks in AFM after exposure to $\mathrm{H}_{2} \mathrm{O}_{2} 35 \%$ bleaching material in Group III (Figures 6A and 6B). The irregularity of the enamel surface looks reduced with smaller and shallow crater, mild depression, and slight pores in SEM and surfaces looks reduced of rough in AFM after application of $\mathrm{H}_{2} \mathrm{O}_{2} 35 \%$ bleaching material with cassava extract in Group IV (Figure 7A and 7B). 

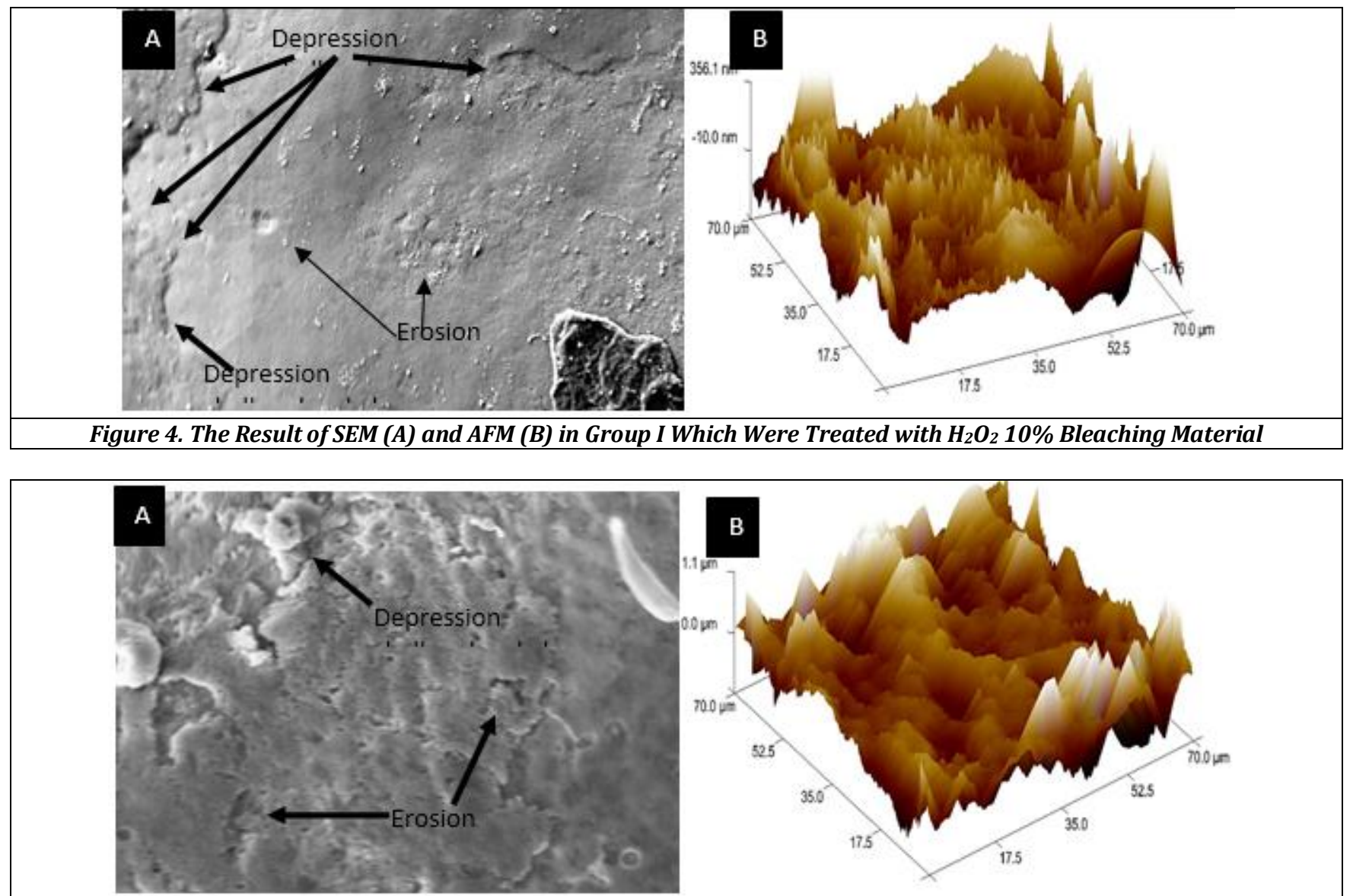

Figure 5. The Result of SEM (A) and AFM (B) in Group II Which Were Treated with Mixture of $\mathrm{H}_{2} \mathrm{O}_{2} 10 \%$ Bleaching Material with Cassava Extract
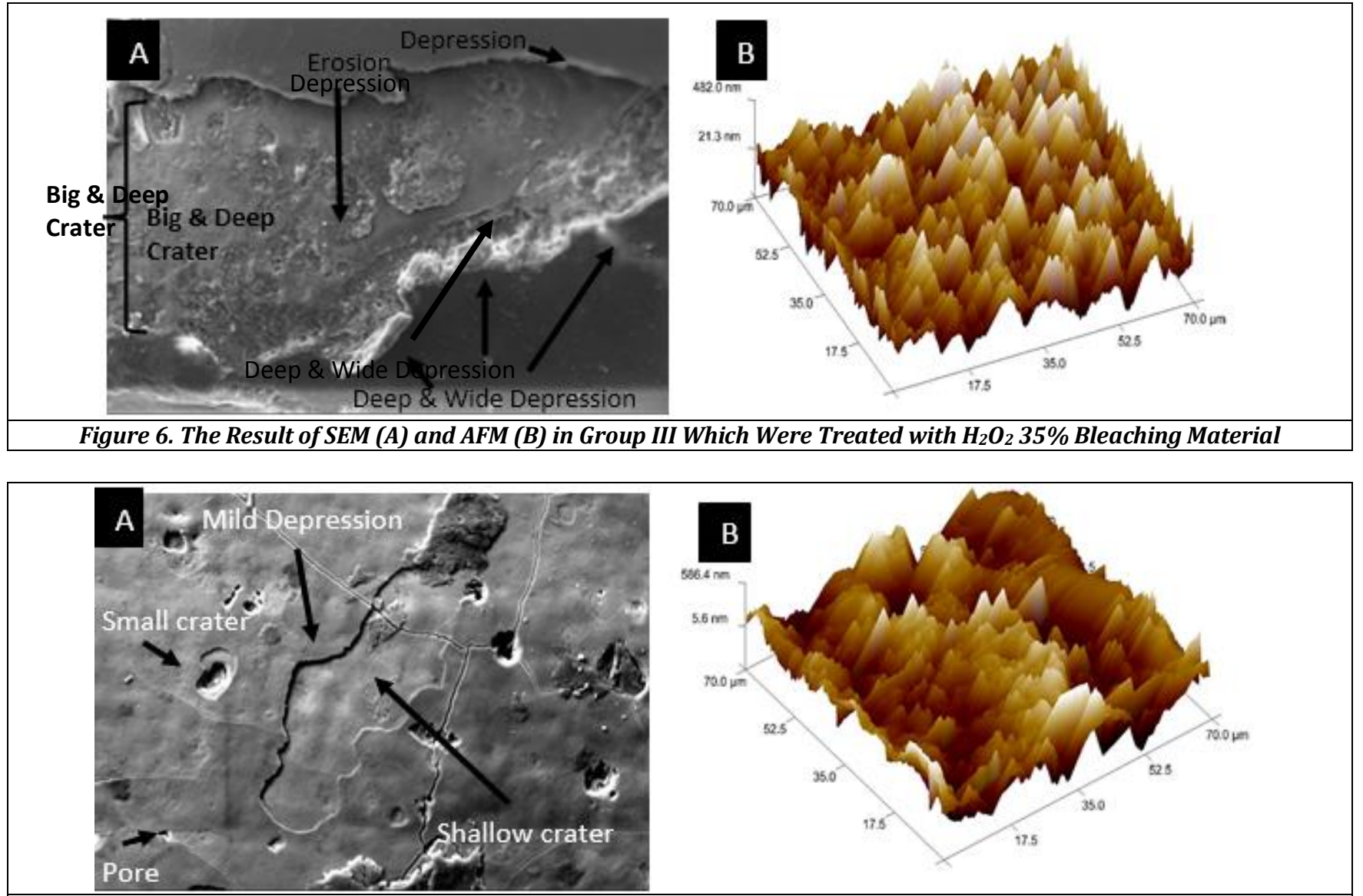

Figure 7. The Result of SEM (A) and AFM (B) in Group IV Which Were Treated with Mixture of $\mathrm{H}_{2} \mathrm{O}_{2} 35 \%$ Bleaching Material with Cassava Extract 


\section{DISCUSSION}

Hydrogen peroxide is a bleaching material that has the ability to penetrate enamel and dentin because of low molecular weight. ${ }^{10}$ Based on the bleaching theory, during the bleaching procedure, it will produce free radicals in the form of unpaired electrons, which will penetrate into the enamel pores and act as oxidizing materials to whiten teeth, referred to as the discoloration elimination process. ${ }^{4,19,20,21}$ However, if the bleaching procedure is carried out excessively, it can make a loss of the chemical element composition in the enamel and make damage structure the tooth. ${ }^{4}$

The acid produced from the bleaching material can vary, depending on the concentration of the bleaching material used. The acid is contact on the enamel surface hence it can cause erosion which is characterized dissolution of organic and inorganic material in the enamel. ${ }^{22}$ The greater of the concentration of peroxide, the more acid will be produced from the bleaching material and hence result in large mineral loss. In this study was found in Group I $\left(\mathrm{H}_{2} \mathrm{O}_{2}\right.$ 10\%) had higher $\mathrm{Ca}$ and $\mathrm{P}$ than Group III $\left(\mathrm{H}_{2} \mathrm{O}_{2} 35 \%\right)$. Berger's research (2014) also reported that with the application of $\mathrm{H}_{2} \mathrm{O}_{2} 35 \%$ bleaching material, a large loss of Ca content $(30.4 \pm 2.8)$ and $\mathrm{P}(15.1 \pm 1.7)$ content is observed as compared to bleaching by $\mathrm{H}_{2} \mathrm{O}_{2} 10 \%$, with Ca value ( $\left.32.8 \pm 3.9\right)$ and $\mathrm{P}(16.8 \pm 2.3) .23$

Unstable free radicals in the form of unpaired electrons come from bleaching materials such as peroxide $\left(0^{-2}\right)$. Peroxide will react and bind to $\mathrm{Ca}^{2}+$ from hydroxyapatite enamel to create a new bond, namely $\mathrm{CaO}$. This $\mathrm{CaO}$ deposition makes teeth look whiter, but this bond is so weak that calcium from hydroxyapatite is easily lost. Calcium release will be also greater, if a higher hydrogen peroxide concentration is used. Hydrogen peroxide can also be a form of diperoxo $\left(\mathrm{H}_{4} \mathrm{O}_{4}\right)$ which has the ability to change the hydroxyapatite structure by replacing $\mathrm{PO}_{4}$ with a diperoxo ligand in order to form new complex bonds and can cause the enamel structure to become brittle. ${ }^{24}$ This is seen in this study, the use of $\mathrm{H}_{2} \mathrm{O}_{2} 35 \%$ bleaching material had lower $\mathrm{Ca}$ and $\mathrm{P}$ rather than $\mathrm{H}_{2} \mathrm{O}_{2} 10 \%$.

In this study, the enamel surface in Group III which was treated with $\mathrm{H}_{2} \mathrm{O}_{2} 35 \%$ bleaching material had a more severe damage on enamel morphology (Figures 6A and 6B) as seen in SEM and AFM compared to Group I which as treated with $\mathrm{H}_{2} \mathrm{O}_{2} \quad 10 \%$ (Figures $4 \mathrm{~A}$ and $4 \mathrm{~B}$ ). The increased in enamel surface irregularities after exposure to $\mathrm{H}_{2} \mathrm{O}_{2} 35 \%$ was also found in the Miranda study (2005). Saleem (2018) also found that enamel surfaces looked more rough and irregular in AFM after exposure to $\mathrm{H}_{2} \mathrm{O}_{2} 35 \%$ bleaching material. This is because the solution of $\mathrm{H}_{2} \mathrm{O}_{2} 35 \%$ bleaching is a higher concentration of bleaching material compared to $\mathrm{H}_{2} \mathrm{O}_{2} \quad 10 \%$ so that it can cause enamel more demineralization. 4,10

Cassava tubers are plants that have many enzymes such as catalase, superoxidase dismutase, phytic acid, anthocyanins, flavonoids, glutathione and rich in vitamins such as vitamin $\mathrm{C}$, vitamin $\mathrm{E}$, and vitamin $\mathrm{A}$. Not only enzymes and vitamins are present in cassava, but also minerals, one of which is calcium (Ca) and phosphate (P). ${ }^{18}$ Cassava plants added to bleaching materials can reduce enamel damage, this is because cassava has $\mathrm{Ca}$ and $\mathrm{P}$ which can enter the enamel with enamel due to the enamel's permeability and hence restore lost minerals, as well as the ability to fight free radicals from bleaching materials. The ingredients that can fight free radicals from cassava are enzyme catalase and superoxidation dismutase against free radicals by producing water and oxygen, phytic acid which reduces developing free radicals, anthocyanins can relocate unpaired electrons, vitamins $\mathrm{E}$ and $\mathrm{C}$ and flavonoids can interfere and stop the radical chain by catching free radical ions such as superoxidation $\left(\mathrm{O}^{2}\right)$, hydroxyl $(\mathrm{OH})$, peroxyl (ROO), and alkoxyl (RO) ions. In this study, it was found that the mixture of cassava extract with $\mathrm{H}_{2} \mathrm{O}_{2} 10 \%$ bleaching material in Group II had Ca and P higher than Group I, and also in Group IV (mixture of cassava extract with $\mathrm{H}_{2} \mathrm{O}_{2} \quad 35 \%$ bleaching material) had $\mathrm{Ca}$ and $\mathrm{P}$ higher than that which has been exposed $\mathrm{H}_{2} \mathrm{O}_{2} 35 \%$ bleaching material alone in Group III. This is because cassava added to the bleaching materials was not only works to fight free radicals, but also contains minerals such as calcium (Ca) and phosphate (P) to re-establish enamel mineralization. ${ }^{18,25}$

Morphological features in Group II (Mixture of $\mathrm{H}_{2} \mathrm{O}_{2}$ 10\% with Cassava extract) showed a better enamel surface with mild depressive features rather than Group I $\left(\mathrm{H}_{2} \mathrm{O}_{2} \quad 10 \%\right)$ which showed many depression and surface irregularity in SEM. Whereas, in Group IV (Mixture of $\mathrm{H}_{2} \mathrm{O}_{2} 35 \%$ with cassava extract) was found smaller crater on the enamel surface compared to in Group III $\left(\mathrm{H}_{2} \mathrm{O}_{2} 35 \%\right)$ with a large crater. When viewed through the AFM, it was also found that the mixture of cassava extract with bleaching material in both Group II and Group IV had better three-dimensional enamel morphology as compared to Group I and Group III which were treated with bleaching material alone. Gopinath's (2013) research shows similar results where morphological results were much better when sweet potato extract mixed with $\mathrm{H}_{2} \mathrm{O}_{2} \quad 10 \%$ or $\mathrm{H}_{2} \mathrm{O}_{2} 35 \%$ compared to the use of $\mathrm{H}_{2} \mathrm{O}_{2}$ $10 \%$ or $\mathrm{H}_{2} \mathrm{O}_{2} 35 \%$ bleaching materials alone due to presence of antioxidants in sweet potato. ${ }^{15}$ Catalase enzymes are present in sweet potato and cassava, which when added to hydrogen peroxide can reduce the energy activation of whitening teeth, hence the time of release for free radical from hydrogen peroxide is short and can reduce formation of grooves or porosity on the enamel surface. ${ }^{15}$

The content of carbon (C) and oxygen (O) in all Groups was not significant ( $p>0.05$ ). This is due to hydrogen peroxide being an unstable bleaching material and can slowly decompose and release oxygen; the reaction of free radicals produced from hydrogen peroxide can be vary vary like as hydroxyl ( $\left.\mathrm{HO}^{-}\right)$, dihydroxyl $\left(\mathrm{HO}_{2}-\right)$ and superoxide anion $\left(\mathrm{O}_{2}-\right)$. Additionally, the final oxidation reaction of hydrogen peroxide produces carbon dioxide $\left(\mathrm{CO}_{2}\right)$ and water $\left(\mathrm{H}_{2} \mathrm{O}\right)$ which are volatile.4,24

\section{CONCLUSION}

The addition of cassava extract to $\mathrm{H}_{2} \mathrm{O}_{2} \quad 10 \%$ or $\mathrm{H}_{2} \mathrm{O}_{2} 35 \%$ bleaching material, can minimize enamel damage and it can be seen that all mineral elements are increased as compared to those without the addition of cassava extract. Therefore, cassava extract can be used as an additive in bleaching materials because it can reduce free radicals from bleaching material and also reduces the presence of calcium and phosphate minerals from the extract. 


\section{REFERENCES}

[1] Nasution AI, Gani BA, Pospos RM. Relationship between fluor concentration and structure pattern of enamel prism in enamel surface after coffee and black tea exposure. World J Dentistry 2012;3(4):284-9.

[2] Avery JK, Chiego DJ. Essential of oral histology and embryology. 3rd edn. London: Mosby Elsevier 2006: p. 97-105.

[3] Riani MD, Oenzil F, Kasuma N. Pengaruh aplikasi bahan pemutih gigi karbamid peroksida $10 \%$ dan hidrogen peroksida 6\% secara home bleaching terhadap kekerasan permukaan enamel gigi. J Kesehatan Andalas 2015;4(2):346-51.

[4] Wang X. Structural aspects of bleaching and fluoride application on dental enamel. Dissertation. Hamburg: University of Hamburg 2009: p. 3-23.

[5] Liwang B, Irmawati, Budipramana E. Enamel microhardness of young permanent tooth after bleaching and remineralisation paste application. Dent J Maj Ked Gigi 2014;47(4):206-10.

[6] Jafkar S. Pengaruh agen aktif bleaching terhadap jaringan keras dan lunak mulut serta bahan restorasi kedokteran gigi. Cakradonya Dent J 2009;2(1):1-82.

[7] Li Y, Greenwall L. Safety issues of tooth whitening using peroxide-based materials. British Dent J 2013;215(1):29-34.

[8] Syafriadi M, Noh TC. Pengukuran kadar kalsium saliva terlarut pada gigi yang dilakukan eksternal bleaching dan dipapar dengan Streptococcus mutans. PDGI J 2014;63(2):63-5.

[9] Kwon SR, Wertz PW. Review of the mechanism of tooth whitening. J Esthes Restor Dent 2015;27(5):24057.

[10] Miranda CB, Pagani C, Benett AR, et al. Evaluation of the bleached human enamel by scanning electron microscopy. J Appl Oral Sci 2005;13(2):204-11.

[11] Ogiwara M, Miake Y, Yanagisawa T. Changes in dental enamel crystals by bleaching. J Hard Tissue Biology 2008;17(1):11-6.

[12] Soares DG, Riberio APD, Sacono NT, et al. Mineral loss and morphological changes in dental enamel induced by a $16 \%$ carbamide peroxide bleaching gel. Braz Dent J 2013;24(5):517-21.

[13] Elfallah HM, Bertassoni LE, Charadram N, et al. Effect of tooth bleaching agents on protein content and mechanical properties of dental enamel. Acta Biomater 2015;20:120-8.
[14] Venkatesan SM, Narayan GS, Ramachandran AK, et al. The effect of two bleaching agents on the phosphate concentration of the enamel evaluated by Raman spectroscopy: an ex vivo study. Contemp Clin Dent 2012;3(Suppl 2):S172-6.

[15] Gopinath S, James V, Vidhya S, et al. Effect of bleaching with two different concentrations of hydrogen peroxide containing sweet potato extracts as an additive on human enamel: an in vitro spectrophotometric and scanning electron microscopy analysis. J Conserv Dent 2013;16(1):45-9.

[16] Saleh N, Widodo Y. Profil dan peluang pengembangan ubi kayu di Indonesia. Bul Palawija 2007;14:69-78.

[17] FAO. The state of food security and nutrition in the world. 2017: p. 1-132.

[18] Montagnac JA, Davis CR, Tanumihardjo SA. Nutritional value of cassava use as a staple food and recent advances of improvement. Comprehensive Reviews in Food Science and Food Safety 2009;8(3):181-94.

[19] Adang RAF, Suprastiwi E, Usman M. Pemutihan gigi teknik home bleaching dengan menggunakan karbamid peroksida. Edisi khusus KPP IKG X IV 2016: p. 254-9.

[20] Joshi SB. An overview of vital teeth bleaching. J Interdiscip Dentistry 2016;6(1):3-13.

[21] Nair M, Nesamani R, Sanjeev K, et al. Effects of single and two step application of antioxidant incorporated bleaching agents on bond strength of resin composite and surface changes in enamel. Biol Med (Aligarh) 2016;8:348.

[22] Pizani AMA, Tholt B, Dias KRHC, et al. Dental bleaching agents with calcum their effects on enamel microhardness and morphology. Braz J Oral Sci 2015;14(2):154-8.

[23] Berger SB, Soares LES, Martin AA, et al. Effects of various hydrogen peroxide bleaching concentrations and number of applications on enamel. Braz J Oral Sci 2014;13(1):22-7.

[24] Yuniarti Y, Achadiyani A, Murniati N. Penggunaan pemutih gigi mengandung hidrogen peroksida $40 \%$ dibandingkan dengan strawberry (fragaria ananassa) terhadap ketebalan enamel, kadar kalsium, dan kekuatan tekan gigi. GMHC 2016;4(1):7-13.

[25] Perchyonok VT, Grobler SR. Tooth bleaching: mechanism, biological, aspects and antioxidants. Int J Dent Oral Health 2015;1(3):1-7. 